PREGLEDN I

ČLANAK

\title{
Revisiting Greek lighthouses: A new perspective in cultural tourism
}

\author{
Ponovno razmatranje grčkih svetionika: nova \\ perspektiva u kulturnom turizmu
}

Paraskevi Kakaroucha, University of West Attica, Dept. of Tourism Management, Athens

ABSTRACT Greece owns one of the most extensive and best organized coastal and open sea lighting systems across the world. Some of the most breathtaking and historic lighthouses and beacons of the Hellenic Lighthouse Network have been characterized as "Monuments of

Keywords: Modern Cultural Heritage" and are available to visitors under certain circumstances. Greek

Lighthouse

tourism,

Hellenic lighthouse

network, lighthouses are austere albeit multi symbolic structures that enchant people seeking refined and reclusive experiences beyond the mass tourism spectrum. This paper aims at succinctly presenting the history of Greek lighthouses and examining the perspective of their valorization in cultural tourism, taking into account their legal framework, ownership status

Cultural heritage,

Cultural tourism,

Pharology and inherent worthiness. Lighthouses represent tangible and intangible cultural values, which deserve to be rediscovered and communicated in ways that ensure sustainability and protection for lighthouse buildings and surrounding areas.

SAŽETAK Grčka ima jedan od najopsežnijih i najbolje organizovanih obalskih sistema svetionika na svetu, kao i sistema svetionika na otvorenom moru. Neki od najfascinantnijih i istorijski značajnih svetionika okarakterisani su kao "spomenici modernog kulturnog nasleđa” i turisti ih mogu

Ključne reči: posetiti pod određenim uslovima. Grčki svetionici su jednostavne, iako višestruko simboličke svetionički turizam, strukture koje očaravaju ljude koji traže prefinjena i izolovana iskustva izvan masovnog turizma.

grčka mreža

svetionika, kulturno nasleđe, kulturni turizam, farologija Cilj ovog rada je da ukratko predstavi istoriju grčkih svetionika i razmotri perspektivu njihove valorizacije u kulturnom turizmu, uzimajući u obzir pravni okvir, vlasnički status i njihovu vrednost. Svetionici predstavljaju opipljive i neopipljive kulturne vrednosti, koje zaslužuju da budu iznova otkrivene i predstavljene tako da obezbede održivost i zaštitu svetionika i njihove okoline.

TIMS Acta (2021) 15, 37-45

\section{Introduction}

Since the bygone era of the archetypal Pharos of Alexandria, the erection of lighthouses has intertwined with the human aspiration to explore and conquer new lands, to expand the boundaries of their knowledge, influence and civilisation, depending on the location and the capacity of each nation or the group of people. In all cases, lighthouses have safeguarded navigation, assuaged mariners' anxiety and nostalgia, saved 
castaways without discrimination of any kind, integrated scientific and technological innovations, represented local identities and amalgamated innumerable universal symbols (Steil, 2010a; Steil, 2010b; Magnani \& Pistocchi, 2017: 124). These are some of the reasons why lighthouses are so appealing to people pursuing unconventional and seclusive tourist experiences outside the mass tourism realm. In addition to their originally practical significance, which diminishes over time due to advancements in maritime management techniques and equipment, lighthouses occupy a vibrant cultural space (MacDonald, 2018: 19) and have been a central axis of many regional and national tourism development strategies.

Regarding Greek lighthouses, they (literally) define a multi-dynamic zone of intersection among mythology, history and technology, which has apprehensively started to be recognized and creatively utilized towards the differentiation and enhancement of the Greek cultural tourism product. This paper aims at succinctly presenting the history of Greek lighthouses, which justifies their characterization as "Monuments of Modern Cultural Heritage", and examining the perspective of their further valorization in cultural tourism, taking into account their legal framework, ownership status and self-evident worthiness.

\section{Objectives and methods}

This paper is the part of a $\mathrm{PhD}$ research being carried out in the Department of Tourism Management (University of West Attica, Greece) and is expected to contribute to the discussion about the tourism valorization of Greek lighthouses that has recently been initiated. The dissertation aims at highlighting the cultural tourism potential of Greek lighthouses, and attempts to address a gap in existing knowledge in the field, since only a limited number of scientific papers and publications refer to lighthouses in a cultural tourism context (e.g. Perišić, 2009; Kovačić et al., 2017; Magnani \& Pistocchi, 2017; Başağaç \& Bilgin Altinöz, 2018). Besides, tourism utilization of Greek lighthouses has not been the central objective in any of the previous academic work and has been studied as a marginal or complementary subject, mainly in engineering students' master theses, which prevalently investigate maintenance, restoration or other



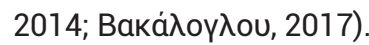

The focus of this study lies in showcasing the cultural heritage that Greek lighthouses represent and their integration into the tourism offer of the country on a more systematic basis. The survey has begun with a literature review of cultural and lighthouse tourism across the globe, and the history of the development of lighthouses, especially in the Mediterranean Basin and the Hellenic Seas. The emphasis is placed on the legislation defining the terms of operation and ownership of Greek lighthouses which seems to restrict their availability to the public. A semi-structured interview tool has been designed in parallel with the bibliographical review; interviews with critical stakeholders, such as Lighthouse Service staff members, and professionals that have promoted Greek lighthouses through their work were conducted in order to provide the qualitative data concerning the scope of the study. The field research findings cannot yet be announced, since the survey is in progress; still, a good portion of the theoretical, historical and legal background of Greek lighthouses could elucidate the basic ideas and practices regarding the topics under discussion, which is the purpose of this paper.

\section{A brief retrospection on the creation and development of the Hellenic Lighthouse Network}

Nature has provided mankind with a plethora of environmental, geological and astronomical 'navigational aids' that have always guided people at sea or on land. Trees, hills, volcanoes and stars undoubtedly assisted people traveling by day or at night prior to the invention of sophisticated and more accurate instruments of orientation (Trethewey, 2018: 7). Rudimentary lighthouses and beacons were also used from time to time, thousands of years before the systematic development of coastal and open sea lighting. Those primitive, mostly temporary fires that served individual needs, were made of trivial materials, such as stone and wood, and were not supervised. Fires were lit at night on shores, promontories and high-altitude places. The same hearths emitted smoke signals at

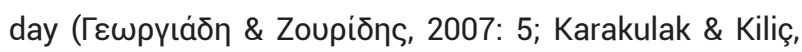
2018: 140). Archaeologists have discovered elevated altars, funeral monuments, incineration terraces and commemorative columns in some of those spectacular or neighboring locations. The use of fire was related to religious ceremonies and sacrifices during departures or returns from sea voyages, in the context of rituals dedicated to appeasing or expressing gratitude to water deities (Steil, 2010b). 
The same primordial structures were the forerunners of fryktories, which were of common use as means of distance communication from antiquity until the Byzantine Era. A chain of fryktories functioned as an optical telegraph that transmitted coded messages across Greek regions in the nighttime. It was a brilliant and reliable method based on torches (frykts) through which the information was disseminated impressively quickly along a sequence of discontinuous geographical points shaping a complex and sizeable network (DeWire \& Reyes-Pergioudakis, 2010: 3-4; Steil, 2010b). The building, maintenance and control cost of fryktoria towers was excessive, which explains why they were under the auspices of the state. Fryktories were considered a military and administrative mechanism of high importance, therefore towers were usually manned with specially trained and lightly armed guards.

The first illuminated tower that was referred to as a lighthouse was the Pharos of Alexandria (Pharos = Фápos is the Greek word for lighthouse that was adopted by the other Latin languages). It was the first prominent and the most legendary lighthouse in history, although fire towers accompanied mariners since the Classical Age $\left(5^{\text {th }}-4^{\text {th }}\right.$ century $\left.\mathrm{BC}\right)$. The Pharos of Alexandria, built on the homonymous islet of the metropolis of that period (beginning of $3^{\text {rd }}$ century $\mathrm{BC}$ ), was characterized as one of the Seven Wonders of the Ancient World. It was designated to reflect and amplify the reputation of the city founded by Alexander the Great as the economic, social and intellectual center of the Kingdom of Egypt. It would primarily symbolize and propagate the omnipotence of the Ptolemaic Dynasty in the Mediterranean Basin (DeWire \& Reyes-Pergioudakis, 2010: 5; Grant, 2018: 23). The design of the Pharos, created by a Greek engineer and architect, Sostratus of Cnidus, was mechanically revolutionary and architecturally exemplary for the time, the "the quintessence of Hellenistic Science" (Vitti, 2009: $300)$. It is reported that the fame of the Pharos spread abroad so fast that artists and engineers represented, glorified or imitated it in their works, without even having visited Alexandria. The Pharos continued attracting travelers, admirers and scholars during the Middle Ages (Vitti, 2009: 308, 311). It should also be pointed out that the Pharos was the only pre-Islamic monument in Egypt that was preserved by all rulers regardless of their religious or ideological beliefs (Папаүعwpyiou, 2019: 25) due to its powerful semiotic and functional association with the Mediterranean Sea (Behrens-Abouseif, 2006: 12; Kassem, 2011: 319). As a result, the Alexandrian Pharos acted as a paradigm for every subsequent lighthouse and obviously affected both the Western (e.g. clock and bell towers, burial monuments, skyscrapers) and the Eastern - mainly Islamic and Hindu - architecture (e.g. minarets, mosques, obelisks) (Steil, 2010b; Cartwright, 2018).

Both the construction of the Greek lighthouses and the development of the Hellenic Lighthouse Network ( $\mathrm{HLN}$ ) follow that prototype. The HLN is one of the most extensive and best organized coastal and open sea lighting systems worldwide. Namely, 1.604 lighthouses, beacons and buoys are nowadays included in the HLN, the creation and growth of which corroborate the Greeks' intertemporal relationship with sea. The Greeks have been a naval nation since the early stages of their history and shipping has been a fundamental component of the country's DNA. The crossroads position (in the Eastern Mediterranean, among three continents) and the rich geomorphology of the country $(15.000 \mathrm{~km}$ of coastline, almost 10.000 islands and islets, mountainous mainland landscape) incited the Greeks to direct their entrepreneurial energy to maritime activities (transport, trade, colony settlement etc). The Greeks gradually dominated the maritime trade along the Mediterranean coasts and displayed their prowess in naval warfare of antiquity, too. The Greeks continued being key actors in the sea trade and playing a major role in shipping across the Roman and the Byzantine Empire. Thus, the Greeks developed their territory and alliances, and diffused their culture mainly via the country's 'liquid highways' (DeWire \& Reyes-Pergioudakis, 2010: 3). An illustrious fleet and an advanced civilization of that magnitude needed and provided, respectively, navigation marks, lights and sounds (^uкоúס̄n, 1917: 211-212). Lighthouses were built in the Greek navigable routes since the Homeric Era (1200 to $800 \mathrm{BC}$ ), while plain lighting pylons flashed in the most strategic ports of the Aegean, Myrtoo and Cretan Seas long before 1650 as evidenced by cartography

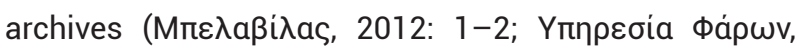
2021).

New torches were seldom established until $19^{\text {th }}$ century (Greece under Turkish Rule since mid-1400s) because of the rough living conditions and the threat of piracy

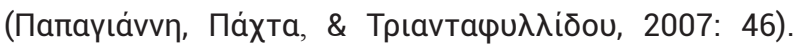
Most of the lighthouses of modern Greece (after the Greek War of Independence, starting in 1821) were installed between 1822 and 1926, by the British (mainly in areas of the Ionian Sea when being under their rule), the French Company of Ottoman Lighthouses (as part of a cost-effective contract with the Sublime Porte) and the newly founded Greek State. Until then, there was 
no central planning for establishing new lighthouses; it was the pressure exerted by the local communities, seafarers and the representatives of European steamship companies that set the criteria and led to decisions.

Greek Prime Minister Charilaos Trikoupis moved forward with a holistic legislation that would modernize and organize the lighthouse network in a period of radical geopolitical rearrangements and infrastructure megaprojects (late $19^{\text {th }}$ century). Stylianos Lykoudis, a Hellenic Royal Navy officer, was assigned by Greek Prime Minister Eleftherios Venizelos to reinvigorate, coordinate and expand the HNL (early $20^{\text {th }}$ century). Although Lykoudis often had to overcome bureaucratic entanglements and even exceed the country's capacities, he managed to increase the quantity and density of Greek lighthouses by $140 \%$. He also realized his vision for a lighthouse system that would be technologically equivalent to other national lighthouse networks of his time. He improved the functionality and efficiency of lighthouses by introducing all his contemporary technical know-how in their operation (e.g. lenses, reflectors, rotation and automation machinery). It is worth noting that the HLN had already incorporated the British lighthouses (after the annexation of the Ionian Islands to Greece, 1864), while the French lighthouses were added in the following decades (after the Treaty of Lausanne, 1923, and a series of decisions from the Permanent International Court of Justice that validated an agreement between the Greek Government and the French Company of Ottoman Lighthouses on the liquidation of their mutual claims in 1957) (Пєтронavıátns, 1940: 14; Thobie, 2004 in:

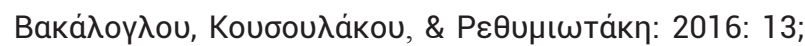

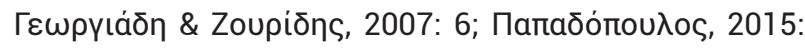
23; Папаүєшрүiou, 2019: 10-16; 41).

World War II almost obliterated the HLN. Lighthouses were vulnerable and high-payoff targets during aerial and sea attacks. Moreover, some of them were vindictively vandalized during the occupation troops' departure in 1944. After the end of Axis Occupation, a large-scale refurbishment plan took place for approximately $1 / 3$ of the lighthouse complexes. The Lighthouse Service had to prioritize the lighthouses to be renovated and preserved, given the post-war economic recession that limited the resources available for the country's general regeneration and the restoration of other historical monuments (DeWire \& Reyes-Pergioudakis, 2010: 13-15). In some cases, the ignorance of specialized techniques and the use of inappropriate or incompatible materials resulted in serious symptoms of pathology in

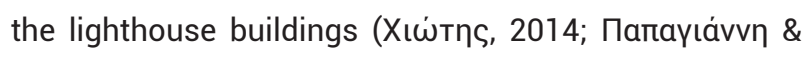
Па́Xта, 2017: 741) and stripped them of their distinctive historical features. In several other cases, the restoration was never completed, while many of the traditional lighthouses subsided and were replaced with unimposing metal skeleton pillars (DeWire \& Reyes-Pergioudakis, 2010: 14-15). Nevertheless, a considerable lighthouse building stock has been preserved, which the Service in charge strives to protect against any further deterioration caused by severe environmental conditions or human indifference and vandalism.

The practical utility of lighthouses surveilling the Greek seaways seems to be minimized. Nonetheless, there are still small fishing boats without electronic equipment or state-of-the-art vessels sometimes encountering faults in their operation - they all search for a familiar and reassuring sign on the horizon. Apart from seafarers appreciating the significance of lighthouses for their safety, the Greek State also recognizes and preserves both tangible and intangible cultural values of lighthouses through regulatory frameworks delineated by international organizations (e.g. International Association of Marine Aids to Navigation and Lighthouse Authorities - IALA), embedded within the national legislation and implemented by the Lighthouse Service. The Lighthouse Service, an independent authority supervised by the Hellenic (Army) Navy, manages, funds, maintains and protects the HLN. About 50 of the 144 traditional stone buildings of the HLN have already been declared 'Monuments of Modern Cultural Heritage' by the Greek Ministry of Culture since they were erected at least 100 years ago. This is an ongoing procedure that is gradually implemented to the historic lighthouses of the country

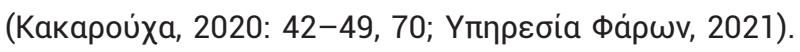
One of the Lighthouse Service's undeviating objectives is the declaration of as many lighthouses as possible as 'Monuments of Modern Cultural Heritage'. The whole staff, attendants and technicians, are committed to this task and work tirelessly, on a restricted budget, to attain this noble goal. Lighthouses are apparently recognized as unrivalled cultural capital by the Greek State, still they are not regularly incorporated in the tourist offer for a number of reasons being discussed in the next section.

\section{Revisiting Greek lighthouses}

Culture could be defined as a set of learned and shared practices, customs, values, arts, intellectual activities and behavioral patterns deriving from distant and 
recent past, even present, that motivates, influences and characterizes its creators and their descendants. Culture creates collective memory and a sense of belonging, ensuring the continuity, cohesion and survival of a

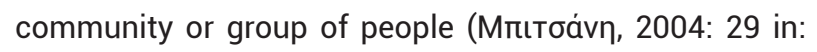
Папаvıколопои́入оu, 2019: 30; MA, 2005 in: Tengberg et al., 2012: 16; Bujdosó et al., 2015: 307-308). Culture connects the present with the past, not only through traces or relics, but also as a living entity that is evolving, (re)evaluated and (re)interpreted in various ways by different generations (Tengberg et al., 2012: 17). For these reasons, culture is perhaps the most emblematic public good, which everyone should be able to enjoy

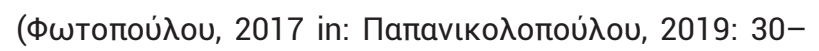
31). The cultural tourism, as a segment or subcategory of thematic tourism, consumes cultural imprints in urban and rural environments; that is why it is so popular in the postmodern personalised experience seeking economy (Pine \& Gilmore, 1999 in: Bujdosó et al., 2015: 311).

Greek lighthouses ideally respond to cultural tourists' demands and pursuits. Their history reveals a wonderful, fascinating and mysterious cultural ecosystem where facts, legends, superstitions, customs and skills are interrelated. Lighthouses and their landscapes encapsulate countless connotations that combine seemingly contradictory or competitive areas of human cognition and practice, such as history with mythology, religion with science, reality with imagination, tradition with progress, earth with heaven, natural with manmade, local with hyper-cultural identities."Precise and appropriate architectural artifacts, masterfully sited and scenographically integrated, lighthouses mark beautifully and poignantly the geometrical-geographical and mythological-poetical intersection of sky, earth and sea, perfect, correct, true and accurate centers in the complex system of cosmic chaos." (Steil, 2010a).

Lighthouses signify strength, stability, generosity, prosperity, tranquility, comfort and geniality. For seafarers and voyagers, a lighthouse is a shield against the dispersing power of the elements (wind, water, earth, fire), a reference point in the vastness of the sea, a spiritual welcome mat (Panek, 2010) during the arrival at a desired destination (Steil, 2010a; Nakajima, 2014; Ekim, 2017: 16). For lighthouse keepers, who are inextricably associated with the existence and the operation of lighthouses despite their profession being obsolete, lighthouses mean livelihood, loneliness, altruism, dignity, pride, responsibility and devotion. For inhabitants of the surrounding areas and visitors, lighthouses are landmarks and narrators of local stories, sights of exceptional energy, beauty and mystery, reminders of the maritime and industrial heritage of a country. For some types of flora and fauna, lighthouse environments are hospitable ecosystems, optimal habitats or spring stopover sites and wintering grounds. For all humanity, lighthouses identify with prevention from maritime accidents that would cost human, material, environmental and developmental losses (Папаס̄ónоu入os, 2015; Какароúха, 2020: 129). Lighthouses encrypt multi-level universal symbols and values. Greek lighthouses epitomize that symbolism and worthiness, so they deserve to be visible not only to mariners, fishermen, lighthouse staff or indigenous and migratory species of wildlife, but also to researchers, naturalists, artists and tourists that are inspired by them.

Reasonably, plenty of dismal stories and morbid rumors that kindle curiosity and imagination are connected to Greek lighthouses. Haunted buildings, the life on the edge, eerie figures, bloodthirsty corsairs, family dramas, unfulfilled love affairs, inscrutable deaths and atrocious crimes are some of the ingredients of the narratives accompanying Greek lighthouses. Reality is often intermixed with imagination. Isolation made conditions very unfortunate for lighthouse keepers, who sometimes invented events that they discovered they had not really happened in sobriety. Human sacrifices in antiquity (there was a sanctuary of Apollo at the site) and the lyric poet Sappho's suicide at Doukato (Lefkas), the Holy Mary's walk on Drepano (Achaia), Saint Paul the Apostle's shipwreck at Vardiano (Kefalonia) en route to Rome, the Turkish spy in Mourtos (Thesprotia), the ghost ship at Cape Apolytares (Antikythera), the inexplicable death of a former minister and the lighthouse keeper's wife's infanticide and suicide in Spathi (Serifos), the love drama of the Algerian shipwrecked girl and the lighthouse keeper in Drepano (Chania) are just some of them (Папабо́пои入оৎ, 2015). In Jules Verne's philhellenic book "The Archipelago on Fire" (1884), some of the most historic lighthouses and beacons of the Ionian Sea (in Antikythera, Methoni, Tainaro, Oitylo) become speechless witnesses of events that determined the History of Modern Greece. A number of modern poets (e. g. Empeirikos, Elytis, Ritsos) were inspired by the shininess and solidity of lighthouses, while contemporary Greek novelists (e. g. Amanatidou, Intzebelis, Kourtzi, Patronou-Papapetrou, Travlou) craft lighthouse stories that captivate their audience. Some of the Greek lighthouses have repeatedly lent their concept, scenery, premises and residents to filmmakers, music 
Paraskevi, K. - Revisiting Greek lighthouses

2021. Fakultet za sport i turizam, Novi Sad, Tims.Acta 15, 37-45

video, documentary and advertising producers. This fact could insinuate that lighthouses are irresistible triggers for human creativity and expression. Moreover, all kinds of the above-mentioned creations could launch an interest in lighthouses that should be taken into account by tourism decision makers.

The Greek lighthouse and cultural heritage laws protect traditional lighthouses consistently since they are a part of both the national defense system and the cultural capital of Greece. These are the main reasons explaining why the access to lighthouses in Greece is permitted exclusively to authorized personnel, and individuals or groups after communication with and approval from the Lighthouse Service. Until recently, there has been no comprehensive valorization and publicity scheme that would promote lighthouses as cultural tourism resources. Occasional events of educational, cultural and recreational nature are organized by the individuals and public or private bodies in collaboration with the Lighthouse Service. Some of these initiatives that take place in lighthouses' courtyards or nearby areas include a wide range of events such as exhibitions, recitals, cultural routes, conferences, sports races etc. and seem to proliferate over time (Какароúxa, 2020: 77-81).

In particular, around 30 lighthouses are allocated for short summer vacation to Hellenic Navy's active and retired staff and their families, while permission to educational and research teams, sports and arts clubs or other interested parties is given upon prior notification (Какароúxa, 2020: 68-74). There are also some museums and permanent exhibitions operating under the Lighthouse Service that are accessible to the public, practically after contact with the Service or the lightkeeper on duty. Moreover, an opportunity for the general public to visit some of the Greek lighthouses is provided annually in the context of celebrating the International Day of Maritime Aids (late June to early July) and the World Lighthouse Day (on the third Sunday of August). Both types of occasions result from Greece's participation in IALA and have proved to be a promising pole of attraction for thousands of visitors who anticipate being guided by lighthouse keepers. The number of visitors has grown since the celebrations' inauguration year 2016 (Kaкapoúxa, 2020: 74). Until Covid-19 crisis outbreak that kept lighthouses closed to tours for public health reasons. The increasing number of lighthouse enthusiasts in Greece indicates that a coherent and long-term lighthouse valorization and marketing plan turns into a necessity that cannot be ignored by tourism policy makers.
Proposals or action plans regarding any further tourism utilization of traditional lighthouses in Greece should be made meticulously, in ways that are in accordance with the national legislation and take into consideration a series of critical factors: the physiognomy of each lighthouse (e.g. structural condition, keeper's presence, location, accessibility, history, other points of interest in the area), visitors' opinions and expectations, local communities' perspectives and so forth. Besides, inherent core characteristics of lighthouses, such as isolation and peacefulness, mandate small-scale activities, away from any commercialization or mass consumption logic. However, visitors could be charged an entrance fee that could contribute to the financial self-maintenance of lighthouses to some extent. The majority of lighthouses are unmanned, so reparation demands are high (Какароúxa, 2020: 125). Of course, lighthouse tourism could be combined with other forms of niche mild tourism (e.g. religious tourism and pilgrimage, wellness, gastronomy, diving, bird-watching, dark tourism). Thereby, capitalizing lighthouses along with other popular or less known contiguous cultural resources could showcase the multifaceted interpretation of lighthouses and rebrand the Greek tourist product.

Lighthouses are neither anachronistic nor fashionable icons that attract only romantic or trendy personalities, respectively. Each one of them has a thrilling story to tell and a remarkable connection with the whole trajectory of Greece in time. For example, most of the lighthouses in or near Attica Region (one of the 13 major administrative divisions of Greece) could be included in a variety of itineraries that could satisfy different groups of people. Vrysaki (Lavrio) and Fonias (Sounio) Lighthouses (about $70 \mathrm{~km}$ from Athens, very close to the International Airport "Eleftherios Venizelos") could be suggested as the intermediate stops on the way to the Attica Zoological Park (Spata), the Mineralogical Museum (Lavrio) or the Temple of Poseidon (Sounio). Sousaki Lighthouse (about from Athens) may attract geologists studying the inactive volcano in the area. Avlida Lighthouse (about 70 $\mathrm{km}$ from Athens) could attract lovers of Homeric poems and Euripidian tragedies, who wish to empathize with the Achaeans before their military campaign against Troy and Iphigenia being ready to be sacrificed in order to appease the goddess Artemis. Psyttaleia Lighthouse (Psyttaleia Island, opposite Drapetsona, Piraeus; the island houses Athens' largest sewage treatment plant), one of the first lighthouses constructed by the Greek State, could attract students of environmental schools. 
Kogchi Lighthouse (Salamina Island, one hour away from the Capital of Greece, by ship) could appeal to pilgrims (Faneromani Monasteri, established in $17^{\text {th }}$ century, provided a shelter for civilians and combatants trying to escape Turkish persecution), poetry lovers (one of the greatest Greek poets, Angelos Sikelianos' house - now museum - is in Salamina) or history fans and researchers (the Naval Battle of Salamis fought between an alliance of Greek city-states under Themistocles and the Persian Empire under King Xerxes, 480 BC). Even 'Lykoudis', one of the latest Navy Lighthouse Missions Ships that was decommissioned in 2021, could be converted into a lighthouse museum.

If a plan of this rationale was put into action, lighthouse keepers would undertake an alternative role and performance that would surpass their conventional duties and largely curate cultural memory. Lightkeepers' vocational outline would have to be adapted to the new framework and broadened by more mediating and cerebral duties, as they would mainly act as cultural facilitators and interpreters, hosts and guides, that is as 'metacultural agents' (Coupland \& Coupland, 2014: 506 in: MacDonald, 2018: 20). Such a swift in lightkeepers' routine would not be unprecedented, considering that visitors used to assemble in or around the Pharos of Alexandria to enjoy fests, or just admire the Pharos (Cleopatra was on of them) 2000 years ago (Al-Bakri, N.D. in Vitti, 2009: 311). Nonetheless, Greek lightkeepers should be trained, in order to modernize their skills and develop their potential because of the public's revisiting of the lighthouses.

\section{Conclusion}

Lighthouses are appealing to people seeking sophisticated and cloistered tourist experiences beyond the mass tourism sector. Some of the most attractive and picturesque lighthouses and beacons of the Hellenic Lighthouse Network are available to visitors under certain terms and conditions dictated by the national legislation about their protection and preservation. On the other hand, practical matters regarding their sustainability have necessitated Greek lighthouses being re-appropriated in a more creative and modern way. Respect to their multiple tangible and intangible values should continue being one of the main criteria according to which at least some of them could be incorporated in the national tourist offer on a regular basis. Small-scale activities that would be designed and approved by the authorities and other interested parties could guarantee the achievement of such a complex and delicate purpose. This paper is part of a PhD research that is being conducted at the Department of Tourism Management (University of West Attica) and is expected to contribute to the discussion about the tourism valorization of Greek lighthouses after the completion of an ongoing field survey and the indepth analysis of the data that will be generated.

\section{STATEMENT}

In her statement, the author confirmed the absence of any conflict of interest.

\section{REFERENCES}

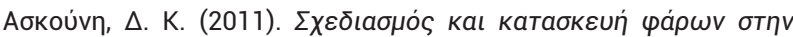
E $\lambda \lambda a ́ \delta a$ [Design and construction of lighthouses in Greece].



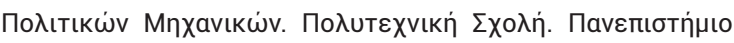
Патри́v [in Greek]

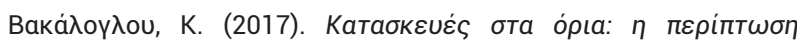

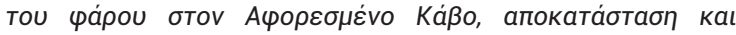

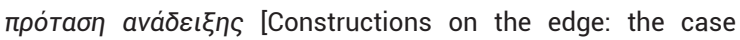
of the lighthouse on Cape Aforesmenos, suggestions on

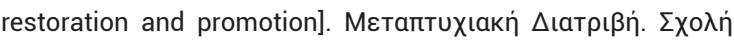

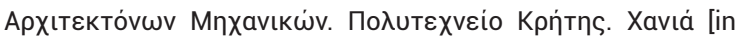
Greek].

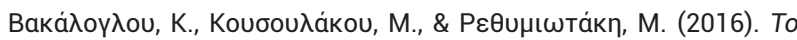

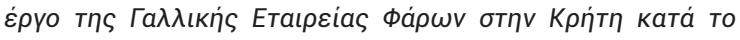

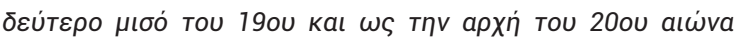
[The work of the French Lighthouse Company in Crete during the second half of the 19th and until the beginning of the 20th

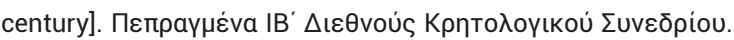

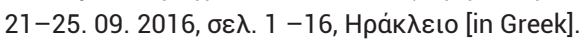

Başağaç, O., \& Bilgin Altinöz, G. (2018). An important maritime heritage: lighthouses on the Aegean coast of Turkey. TÜBAKED, 17, 141-159.

Behrens-Abouseif, D. (2006). The Islamic History of the Lighthouse of Alexandria. Muqarnas, 23, 1-14.

Bujdosó, Z., Dávid, L., Tozsérc, A., Kovács, G., Major-Kathi, V., Uakhitova, G., Katona, P., \& Vasvári, M. (2015). Basis of heritagization and cultural tourism development. Procedia -Social and Behavioral Sciences, 188, 307-315.

Cartwright, M. (2018). Lighthouse of Alexandria. 24. 07. 2018. Available at www.ancient.eu/Lighthouse_of_Alexandria/.

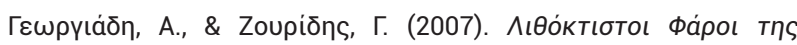

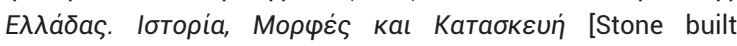
Lighthouses in Greece. History, Forms and Construction]. 10



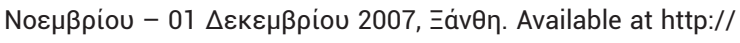
infoidk.arch.duth.gr/idk1/praktika.html [in Greek]. 
Grant, R. G. (2018). Sentinels of the Sea: A Miscellany of Lighthouses Past. London: Thames \& Hudson Ltd.

DeWire, E., \& Reyes-Pergioudakis, D. (2010). The lighthouses of Greece. Sarasota, Florida: Pineapple Press.

Ekim, Z. (2017). RUIN-OPHILIA. Preserving Cultural Narratives of a Lighthouse through Controlled Ruination. Thesis, Master of Architecture (Professional). Faculty of Graduate and Postdoctoral Affairs, Azrieli School of Architecture and Urbanism, Carleton University. Ottawa, Ontario, Canada.

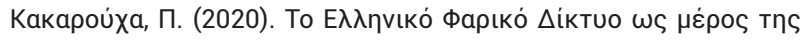

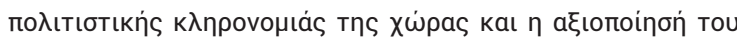

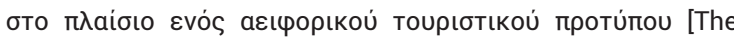
Greek Lighthouses Network as part of the country's cultural heritage and its valorisation in the context of a sustainable



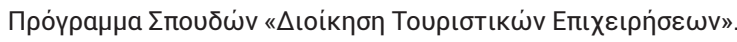

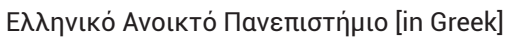

Karakulak, M., \& Kiliç, H. (2018). Illuminate a Steamship Route: Steamships in Cyprus and Lighthouses of Cyprus (18501878). Akademik Bakış, 11(23), 139- 161.

Kassem, A. A. M. (2011). Renewal of the memory of Pharos (The ancient lighthouse of Alexandria). 2nd International Conference on Humanities. Historical and Social Sciences, IPEDR. 17, pp. 275- 279, Singapore: IACSIT Press.



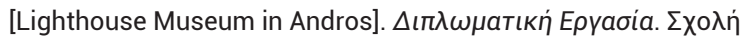

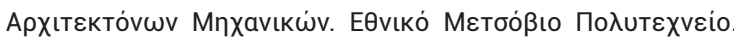
AӨńva [in Greek].

Kovačić, M., Markelj, M., Favro, S., \& Perišić, M. (2017). Are the Lighthouses Only a Croatian Cultural Story or do They Have a Human Role in Tourism? Conference "Local Identity and Tourism Management on World Heritage Sites", April, Coimbra, Portugal. Available at https://www.researchgate.net/ publication/320323053

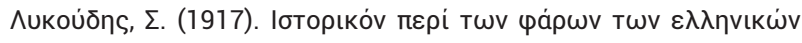

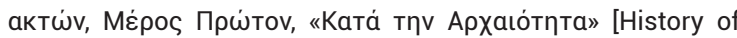
lighthouses of the Greek coasts, Part One, "In Antiquity"].

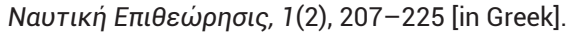

MacDonald, S. M. (2018). Sentinels by the sea: keeping as an alternative tourism performance. Text and Performance Quarterly, 38(1-2), 19-37. Available from https://doi.org/10.1 080/10462937.2018.1457172.

Magnani, E., \& Pistocchi, F. (2017). The Role of Lighthouses in the Construction of Coastal Identities. Journal of Tourism, Culture and Territorial Development, 6, 123-143.

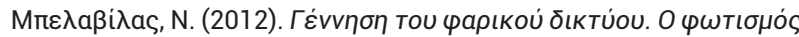

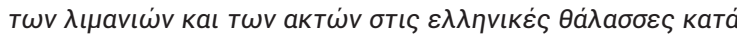

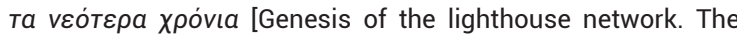
lighting of ports and coasts in the Greek seas in modern years] Available from https://bit.ly/205wrzO [in Greek].

Nakajima, Y. (2014). Lighthouse in our Landscape. Available at https://www.researchgate.net/ publication/264193033.

Panek, J. (2010). The Lighthouse - As A Symbol. 31. 01. 2010. Available at http://www.aseekersthoughts.com/2010/01/ lighthouse-as-symbol.html.

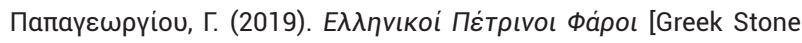



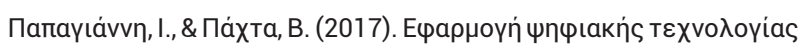

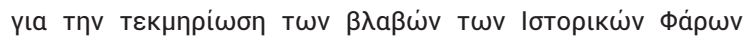




the documentation of damages in Historic Lighthouses and indication of materials and methodologies of compatible and

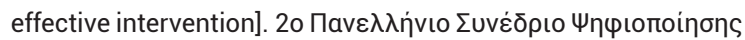

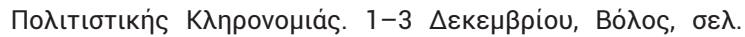
739-745 [in Greek].

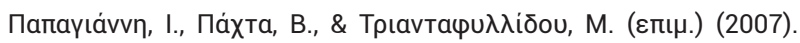

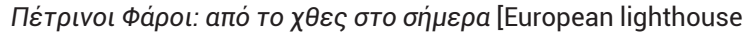

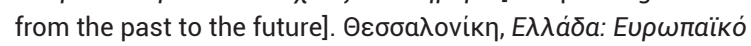
Про́үранца Culture 2000 "EC-PHAROS".

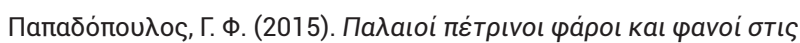

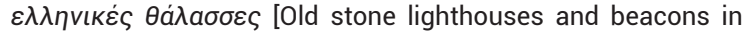
Greek seas]. AӨńva: $\Omega$ KEANI $\triangle \mathrm{A}$ [in Greek].

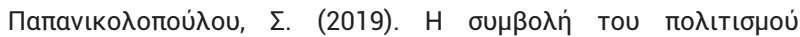

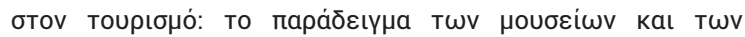


tourism: the example of museums and archeological parks].

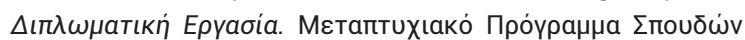

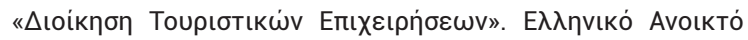

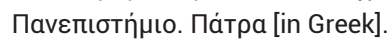

Perišić, M. (2009). Lighthouses as a part of tourist offer being specific tourist destination. Interdisciplinary Management Research, 5, 381-395.

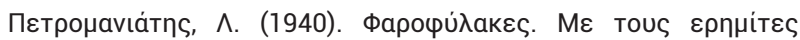



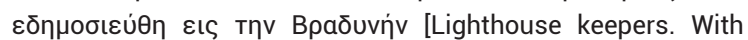
the hermits of the Greek coasts, An original report published

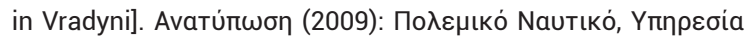
Іоторіас Nautıкoú [in Greek].

Steil, L. (2010a). Metaphysical Archaeology of Lighthouses (Part I). American Arts Quarterly, 27(2). Available at www.nccsc.net/ essays/metaphysical-archaeology-lighthouses-part-i.

Steil, L. (2010b). Metaphysical Archaeology of Lighthouses (Part II). American Arts Quarterly, 27(3). Available at www.nccsc.net/ essays/metaphysical-archaeology-lighthouses-part-ii.

Tengberg, A., Fredholm, S., Eliasson, I., Knez, I., Saltzman, K., \& Wetterberg, O. (2012). Cultural ecosystem services provided by landscapes: Assessment of heritage values and identity. Ecosystem Services, 2, 14- 26.

Trethewey, K. (2018). Ancient Lighthouses: And Other Lighted Aids To Navigation. Torpoint, UK: Jass-Fusion Books.

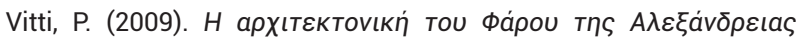
[The Architecture of the Pharos of Alexandria]. Mєтáppaon

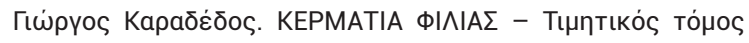

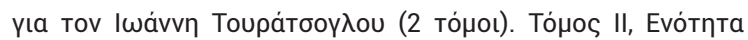

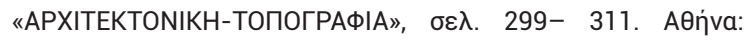



Yпnрєбia Фápwv [Lighthouse Service], (2021). https:// yf.hellenicnavy.gr [in Greek].

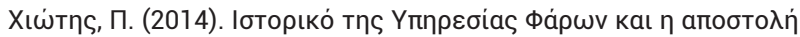
TnS [History and mission of the Lighthouse Service]. 17. 02.

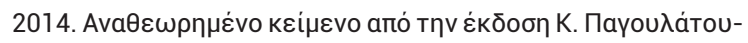

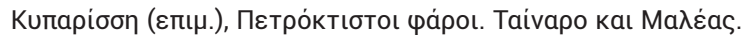

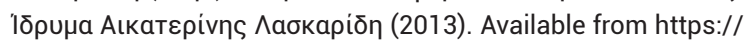
bit.ly/2OKFAOX [in Greek]. 
Paraskevi, K. - Revisiting Greek lighthouses

2021. Fakultet za sport i turizam, Novi Sad, Tims.Acta 15, 37-45

Datum prijave: 09. 06. 2021.

Datum prihvatanja: 24. 06. 2021.

\section{Kontakt}

Paraskevi Kakaroucha, Phd candidate, University of West Attica, Department of Tourism Management, Athens, Greece

E-mail: pkakarouha@yahoo.gr 